\title{
The Impact ofWord Of Mouth Communications on Customer Acquisition in the Construction Industry. A case of Building Contractorsin Masvingo, Zimbabwe.
}

\author{
Mr. K. Dhliwayo \\ Lecturer, Department of Management Studies, Great Zimbabwe University, Zimbabwe.
}

\begin{abstract}
This article intends to explore the impact of Word of Mouth communications on customer acquisition in the construction industry. Its main objective was, to find the extent of applying incentives in Word of mouth communications as used by building contractor. This was due to the fact that Word of Mouth communications have been emphasised in many different industries and have achieved positive results especially when incentives were paid as a deliberate plan for marketing complex services and products. This article sought to find the extent of using word of mouth strategy in the construction industry since this industry is complex especially to new house owners.The study involveda sample of one hundred and twenty respondents whowere randomlypicked from a list of contractors registered with theMasvingo City Council. The researcher got personal details of contractors from City Council house inspectors, that is addresses, cell phones and company names and it was easy to conduct them. The researcher used a self-administered questionnaire to gather primary data required. The major findings of the research were that Word of Mouth communication method, customer to customer referrals, business cards, and cell phones were mainly applied in most contractor firmsto acquire new customers, but surprisingly most contractors although they appreciated the role of referrals and word of Mouth communications, they did not want to pay incentives to motivate satisfied customers who refer others to them. This implies that contractors have an attitudinal problem caused by lack of knowledge of the benefits of Word of Mouth and referrals to the companies. It is therefore essential for contractor managers to deliberately embrace the idea of paying incentives as a strategy for business growth and survival since competition is intensifying in the construction industry.
\end{abstract}

Key terms: Word of Mouth, Communication, Customer Acquisition, Services, Construction industry.

\section{Introduction}

Since the 1960s, much has been researched on Word of Mouth (WOM) communications and its importance in influencing customer decision making. This research area became interesting because Word of Mouth communication was seen by potential clients as a more credible and trusted information source since it was generated from customers themselves than coming from the business (Arndt 1967b; Silverman 1997). There is enough research evidence that Word Of Mouth has an effect on consumers' actions (Banerjee1992, 1993). Again researches were done in other industries such as purchasing of services (Zahorik and Reiningham 1996), and diffusion of innovations (Whyte 1954). Lovelock (1996) says that business managers may have neglected the important aspect of controlling Word Of Mouthcommunications, taking it to be irrelevant to management work since it originates from customers. In Zimbabwe the deregulation of the construction industry after independence in the late 1980s, opened new opportunities for Small to Medium construction firms to start businesses inthisnew industry. During that time the supply of construction services was lower than the demand for them. Later on the demand for construction services was exceeded by supply as more firms entered this industry since it was attractive due to its profitability and then there was need for construction firms to use some form of promotions. The aim of this study was to assess the extent of use of business sponsored WOM communications in the construction industry in Zimbabwe. In order to give an insight into the ways customer to customer WOM communications can be fully utilised to boost business for individual members of the industry. The second aim is to determine the incentives that can be relevant for use in the construction industry in Zimbabwe because each market has its own business culture. Although research in WOM has been done in developed countries, no research was done to assess the effects of WOM communications in Zimbabwe particularly in the construction industry.

The Small to Medium firms in the construction industry in Masvingohave operated in thetradition of not promoting or advertising theirbuilding services as a strategy to acquire new customers. The satisfied customers from different contractors, got involved in passing business talks just on their own initiations recommended the construction service providers to potential customers for the good of it and not for any money or benefits from either the service providers or from the recommenders. The building and construction sector in Zimbabwe comprises of all companies large,medium and small that are involved in either the manufacturing or 
provision of construction materials and/or services. This paper intends to focus on the WOM communications of small to medium firms that provide building services to standsand house owners in Masvingo urban. These SMEsprovide services such as brick moulding, brick lying, plastering, flouring, roofing and also painting until the house is ready for occupation.

\subsection{Research objectives}

A study on the impact of Word Of Mouth communication (Katz and Lazarsfeld 1955) found that word of mouth was seven times more effective than mass media advertising in influencing customer product or service choice. Sometimes later, more studies on Word of Mouth marketing have shown that an effectively managed incentivized Word Of Mouth communications can create favourable buying behaviour from those who solicit for the information (Blodgett et al 1993), , Moore et al (2004).Therefore with this in mind Word of Mouth communications have the potential to yield favourable results for organizations as long as there is enough motivation.

\subsection{Objectives of the study:}

i) To find the extent of applying incentives in Word of mouth marketing by building contractor firms.

ii) To determine other environmental factors that affect the need for incentives in Word of Mouth communications in the sector.

iii) To assess how much business promotion is used by building contractor firms

\subsection{Word of Mouth:}

\section{Theoretical Basis}

Most authors have found it difficult to define Word of Mouth (WOM) precisely (Carl, 2006; Nyilasy, 2005). Arndt (1967) defines WOM as 'face-to-face communication about a brand, product or service between people who are perceived as not having connections to a commercial entity'. A more general definition was by the American Word of Mouth Marketing Association (WOMMA, 2008) as 'the act of consumers providing information to other consumers'. As noted above, the term WOM refers to marketing that influences selling of products or services through a natural informal way as given from consumer to consumer. Word Of Mouth (WOM) communications can be describedas a customer-dominated marketing communication whereby the communicator is not part of the product or service provider. Its nature dictates that potential customers see it positively and is perceived to be credible, trusted than the business generated communications. (Schiffman\&Kanuk, 1995; Arndt, 1967). The effectiveness of word of mouth communication is based on its source, that is a person known to the potential house owner and or is someone who is well trusted by the potential client of the contractor. Recommendations from such sources are more authentic and believable to people who are looking for it, than polished statements from advertising and sales promotion which is tailor made by the construction firm. Word of mouth communication is influential on customer's behaviour especially on their information search stage, evaluation of alternative solutions, and even on buying decisions (Cox, 1963; Brown \&Reingen, 1987; Gilly, \& Graham, 1998; G. Silverman, 2001). Word of Mouth talks give details about the service quality expectations, expenses to be incurred and the message detail will depend on the understanding of the one asking, especially in the construction sector where the service is experienced after purchase and product evaluation comes after a complete project i.e. Post purchase behaviour of the purchase decision is crucial (Cox, 1963). The Word of Mouth phenomena has attracted great attention in most business sectors as well as in the academics area. The sharing of experiences among people who live in the same area, relatives and friends as noted above tend to influence customers` choices and their purchase decisions. (Arndt 1967, Whyte 1954) Word of Mouth communications shared by customers helpto mould the expectations of potential buyers, help peg the level of service quality and create confidence in the abilities of service providers.(Anderson \& Salisbury (2003) Zeithaml\&Bitner(1996).

Another important reason for applying Word of mouth marketing strategy is that it makes reasonable sense for small firms in the construction sector in that it is affordable, it creates a platform on which to build business competitiveness and all players large and small can compete fairly. Word of Mouth communication can also win public awareness and already completed projects can build reputation that is built over time and work as appoint of reference for new customers. In the construction industry sector in Zimbabwe customer to customer Word of Mouth communication is from those who have gone through the construction of a house or shop than from the building contractors themselves. 


\subsection{Communication:}

A communication network can be defined as a situation which enhances the passing of essential buying or selling information and also individual buying experiences amongst closelyrelated groups of people. In developed markets communication networks are formalised, for example Europe Consumer Centers network(ECC-Net) which has been in operation from 2005. Its purpose was meant to provide information to its members so that they could make informed buying decisions. In developing countries like Zimbabwe, consumer social communication networks are informal,unregistered but still they exist in their social groups such as residential areas, churches, work places and in social clubs as well as friendships and acquaintances who share information on personal experiences in purchasing and selection of services providers. Relationship closeness among social groups generally ends up in Word of Mouth communications which can influence buying behaviour which brings positive results to business success through more and more potential customers being lured into dealings with the construction businesses due to referrals from experts and satisfied customers (Richins, 1983). Another important aspect that improves communication networks among customers is interpersonal trust which creates confidence, reliability and integrity among customers in the construction of industry (Morgan and Hunt 1994).

In any set up of social communication networks there are two different forms of communication ties namely strong and weak ties. (Brown \&Reingen 1987). In any business operation it's important to identify the 'strong ties' communication networks since these have stronger influence on group members' purchase decisions especially in the service sector like the construction industry business. The connections within a single group are normally strong while ties formed between severalgroups or two different groups are weak ties. (Granovetter 1973) In the case of the construction industry strong ties are networks created by land lords who are building and those who have just finished construction. Their long time experiences in the sourcing of building materials, choosing the most appropriate service providers, handling stage by stage approvals from City Council inspectors and how to get highest quality service from contractors.

\subsection{Customer acquisition:}

Marketing strategies should change as the market also change on day to day bases and previously accepted methods of doing business cannot be accepted now, therefore firms change from being company oriented (push strategy) to customer oriented (pull strategy) which has also become a shift of power and control from the company to the customers. Ntale et al (2013) pointed out that presently consumers have become more powerful to determine what they see and how they get to the information they see.This position meansthat consumers are no longer tossed to and fro in responding to company sponsored mass communication strategies like advertising, posters, sales promotion and even by public relations activities. Therefore in responding to this paradigm shift, marketers have turned to relationship marketing, which seeks to create a lasting relationship with customers as a way of being more innovative in acquiring and keeping customer loyalty. (Eisingerich\& Bell 2007)

Therefore customer to customer marketing and in particular Word of Mouth communication can be the most successful way to acquire and retain customers in the construction industry, since advertising is losing itsgrip and favour of customers. Few or no potentialhouse owner in Masvingo can select a contractor from a newspaper advert or from bill board advert before conducting friends, relatives and other house owners who have experiences in the construction of houses in Zimbabwe. This results in customer to customer sharing of information being more important and it leads to the choice of a contractor. In developed countries Word Of Mouth marketing is a company initiated and sponsored business activity and it is measured as an effective marketing tool, unlike in the construction industry in Zimbabwe where the contractors give nothing to motivate satisfied customers to refer others to their construction firms. The effectiveness of incentive giving in the use of Word Of Mouth marketing have been studied and well explained(Blodgett et al (1993), Moore et al (2004).

\subsection{Services:}

A service is an "activity or line of activities of a more or less intangible form that normally, but not always happen in personal interaction between a consumer and service provider's employees and/or physical resources or goods and/or systems of the service provider, which are provided as solutions to customer problems." (Susman, Warren and Ding 2006). Marx Van der Walt (1998) defines 'commercial services as independent, separate, identifiable, intangible, need-satisfying activities destined for ultimate consumers and industrial users and are not necessarily related to the sale of a product or service.'

Usually, when customers and service provider employees are in constant touch, inter-personal cohesiveness create smooth delivery of service and customer become more satisfaction with the service. (Tidd and Hull, 2002). There is proof that when a customer is satisfied with the service or product, he/she will be eager to tell others about it, and also dissatisfied customers can bitterly inform others about their bad experiences with a service or a product with the purpose of getting sympathisers. (Blodgett et al., 1993; Brown and Beltramini, 
1989; Richins, 1983; Wilson and Peterson, 1989). In support of the above view,Richins (1983) says that there is an interesting tendency that one will use negative WOM communication because of a high degree of dissatisfaction and if he /she perceives that the service supplier is adamant to respond to complaints. The fact that a satisfied customer will tell only three other customers about how he/she enjoys a product or service, while a dissatisfied customer will tell eleven others about the bad experience suffered,makes it more critical for any construction firm which depends more on Word of Mouth communication to influence what is said about them.Potential customers normally get answers from Word of Mouth communications sources to fill up information gaps created when they cannot get it from their own immediate sources (Internal) such as acquired knowledge, personal understanding and convincing facts. (Bloch et al., 1986; Burnkrant and Cousineau, 1975)

According to Murray (1991) services are naturally risky to acquire and buyers of services take more care before they choose the service or service provider and they are forced to take cautious steps in choosing the service provider. Another aspect of concern in the acquiring construction services is that a mistake made in brick laying or plastering become difficult to rectify after it has been done. As highlighted above many house owners have suffered loss of building materials and money after their projects were condemned for substandard construction work. Therefore due to its technical nature house owners (consumers) cannot evaluate and test the work of a contractor before buying the service. Therefore service quality, reputation of the contractor and reliability of service are major aspects to consider when handling technical products or services and in particular selecting a service provider.

\subsection{Construction industry:}

According to the African Federation for Construction Contractors Association (AFCCA) which was formed in Cairo in 2006 the construction industry has been arrangedin 25 operational categories suchas brick laying, plastering, roofing, tiling, electrification, brick moulding, etc. In the Zimbabwean situation, building contractors provide labour and house owners provide building materials. In rare cases the building contractors is required to offer fix and supply services, where the contractor has to supply all the building materials and also provide the construction services. In Masvingo urban and all other cities in Zimbabwe, all construction firms are registered with the City Council and potential house owners may be given a list of names and phone numbers of registered building firms to choose from.To win customers the promotional strategies used are contractor`s boards with names, house numbers and cell numbers, advertising, picture exhibitions of structures they would have made.

In the construction industry Word of Mouth communications seems to have three key branches that impact its effectiveness in influencing the decision to choose a service provider.

2.5.1 Experience: Members in the construction industry use something that delivers a personal experience which is new, novel, different and unique, enthusiastic and satisfying noted need. Generally, the Word of Mouth communications happenswhen members experience service level that exceeds their level of expectations especially in service offerings. (Kuokkanen 1997; Westbrook 1987; Oliver 1980; Swan and Oliver 1989) in (Martin , 2006) In operation contractors take photos of houses they have completed to show that they are capable to do an exceptional work

2.5.2 Involvement:It's whereby satisfied customers have been involved in building or are actually involved in the building than just assumes how it is done. Both recommenders and potential customers find construction personally essential and very relevant and all are highly involved.(Zaichkowsky, 1985; Feick\& Price, 1987; Richins\& Root-Shaffer, 1988 ;) in (Martin, $2006 ;)$

2.5.3 Incentives: In the construction industry satisfied customers canput extra effort on passing Word of Mouth communications to those looking for contractors when they get incentives than when nothing is given (Martin 2006) Giving incentives to satisfied consumers who to promote the business can be through the following methods;percentage of business created, flat figure, money offs on amounts due, rewards and discounts can be a powerful method even in contractors firms. (Biyalogorsky, Gerstner \&Libai 2001)

\section{Methodology}

This study takes a descriptive survey research design which aims to ascertain the extent to which Word of Mouth marketing strategy has been used by the Small to Medium construction firms in Masvingo urban and also see what can motivate customers to use WOM to promote small to medium businesses in the construction industry(Herr et al 2002). The design afforded the researcher an opportunity to establish the effectiveness of solicited referrals than unsolicited word of mouth communication. The targeted population comprised all the Contractors who are building houses, dura walls or business shops in the six identified residential areas. The simple random sampling technique was adopted. From the list of building contractors as registered at the City Council inspectorate office there are 500 contractors registered and $24 \%$ were randomly selected as the sample 
to be studied ,so the sample was 120 but five questionnaires could not be returned, which is a $4 \%$ and $96 \%$ were returned.The self-administered personal interviews (drop and pick) were used for the advantage that respondents were allowed to complete at their own time. A structured questionnaire was used as the main instrument to gather data from the respondents. The questionnaire was tested before its final use with 12 randomly selected constructors (constituting $10 \%$ ) from two residential areas (Hillside and TargetsKopje) to check on its usage and examine its validity (Malhotra and Birks 2006). After making amendments to the noted flaws in the questionnaire itwas distributed to 15 contractorsfrom old residential areas(Mucheke 15, RunyararoWest 15, Rujeko 15, and HlalaniKhuhle 15) and 30 constructors from new residential areas ( Hillside 30, Targets Kopje 30) as per plan.A three point Likert scale (Disagree; don't know and Agree) was used to measurethe effectivenessof the Word of Mouth communications

Among contractors who were in the business of building for some time now. The aim of this study was to establish the relationship between the choice of a service provider and Word of Mouth referrals from other satisfied customers. Descriptive statistics from SPSS vision 14.0 was used to analyse these relationships.

IV. Research Results

Table 4.1 Responses on options to acquire new clients by contractors

\begin{tabular}{|c|c|c|c|c|c|}
\hline Statement on acquiring new contractor & $\mathrm{N}$ & Minimum & $\begin{array}{c}\text { Maximu } \\
\mathrm{m}\end{array}$ & Mean & Std. Deviation \\
\hline Get new customers by newspaper adverts & 115 & 1 & 3 & 1.91 & 1.001 \\
\hline Satisfied customer is a sources of clients & 115 & 3 & 3 & 3.00 & .000 \\
\hline Exhibitions assist to get new clients & 115 & 1 & 3 & 2.40 & .574 \\
\hline Prices are rising in the building sector & 115 & 1 & 3 & 1.94 & .939 \\
\hline Get customers through advertising & 115 & 1 & 3 & 1.93 & 1.003 \\
\hline A group of sales reps bring new clients & 115 & 1 & 1 & 1.00 & .000 \\
\hline Customer to customer word of mouth is good. & 115 & 1 & 3 & 3.00 & .000 \\
\hline Pay referrers for referring clients & 115 & 2 & 3 & 2.20 & .402 \\
\hline Want to pay incentives to WOM sources & 115 & 1 & 2 & 1.60 & .492 \\
\hline Competition too much in the sector & 115 & 3 & 3 & 3.00 & .000 \\
\hline Need training on Word of Mouth marketing & 115 & 1 & 3 & 2.29 & .962 \\
\hline Incentives are beneficial to contractor firm & 115 & 2 & 3 & 2.64 & .481 \\
\hline Word of Mouth acceptable to all new clients & 115 & 3 & 3 & 3.00 & .000 \\
\hline $\begin{array}{l}\text { Use of metal boards is effective in getting } \\
\text { clients(Name, cell phone no, address,) }\end{array}$ & 115 & 3 & 3 & 3.00 & .000 \\
\hline $\begin{array}{l}\text { Business cards are a strong tool to get clients } \\
\text { Valid N (listwise) }\end{array}$ & 115 & 2 & 3 & 2.65 & .478 \\
\hline
\end{tabular}

The respondents indicated that they disagreed that they acquire new customers through the use of advertising. This was reflected in the table by the mean values of 1.21 and 1.91 which failed to match the mean value of 3.00. This may be assumed that most small to medium firms do not use newspapers, radio, or magazine advertising which normally cover national and regional areas than the urban area.Respondents have shown that they did not engage sales reps to acquire new clients as given by a mean value of (1.00), and they used exhibitions at trade showswith a mean value of (2.40)and this was above average standard mean. This means that respondents in this industry did not employ sales reps to market their construction services and have a mandate to display their operator boards which display their names, addresses, and cell phone numbers and has been used as a promotional tool for them.

Respondents indicated that customer to customer word of mouth communication was an effective way to acquire new clients, with a mean value of (3.00)and a standard deviation of (.000) it shows that all respondents accepted this statement and again they accepted a statement that satisfied customers influenced new comers in the industry by mean value of (3.00), they also unanimously agreed that information boards played a major promotional role with mean value of (3.00) and a standard deviation of (.000), respondents have shown that business cardswere effective in the acquisition of new clients, it got a mean value of (2.65) which is a positive influence in new client decisions to choose a contractorThese results may indicate what methods most contractors apply like customer referrals, displays of boards at sites and a few using business cards.

Respondents were also asked to evaluate the nature of the industry of operation. They indicated that the prices in the construction sector were stable with a mean value of (1.94), but all indicated that competition was going up in the construction industry with a mean value of (3.00) and thestandard deviation mean value was (.000). This contrast could have been due to their bias regarding their own prices of the building service but they all agreed that competition was too much for them. There is no deviation from the mean as reflected by a 
standard deviation value of (.000) for this variableindicates thatthis market has the same view on intensity of competition. Finally respondents were asked to give their view regarding payment of incentives as a tool to motivate referrers so that they deliberately refer potential clients to their favourite contractors.

Overall responses fell in the mean range of 2.40 to 3.00 for the quarter of the options which were used to acquire customers in the construction industry, the remainder of the options were weaker in their influence to the acquisition of clientsand generally the contractors were clear that they disagreed with the idea of paying incentives although they appreciated the importance of having Word of Mouth communications to boost new clients decisions on choosing service providers. These results reflect that generally, respondents indicated that they either don't know or disagree that indeed the Word of Mouth marketing is effective in creating interests in the service providers in construction industry. An indication of this nature of results may show that respondents (contractors) may not know the benefits of a deliberate marketing efforts as compared to results from natural market efforts on business performance. It may also be a question of ignorance about the growth potential available to a business if a deliberate effort is used than to leave the firm grow naturally or even die naturally. Most of the contractors require training to be equipped with marketing information regarding the influence of the Word Of Mouth communications and how effective each SME can effectively apply this strategy for growth and even survival, since all have noted that competition is intensifying daily in this sector.

\section{Implications for managers}

East et al. (2005) reported that Word Of Mouth communications have impact on service provider choicethan company advertisements or even company personal selling strategies. To sum up this study, it has been highlighted that in Zimbabwe the construction industry can use Word of Mouth communications more effective bydeliberately infusing it into the firm's promotional and growth strategies and definitely more business will come their way.Misner(1999), providesevidence that Word of Mouth referrals are a critical element for the construction firms that intend to increase market share in this competitive environment, and also note that WOM communications may have long-lasting impact than the traditional marketing strategies.Managers of the Small to Medium Enterprises in the construction industry shouldtherefore closely assess the way they get new customers and come up with some forms of incentives to motivate old customers to influence potential customers to engage specific construction firms. Presently the construction market demands innovative managers who are always monitoring the changes in the economic environment and grab opportunities ahead of competitors because only those that deliberately acquire and manage new customer can survive in this fast moving market.

\section{Further Research}

This research paper was carried out in Masvingo town and therefore it might not represent the whole construction industry in the Zimbabwean market and it was focused on the impact of Word of Mouth communications in this industry but still there is potential to study the use of Word of Mouth marketing incentives in other industries. Hence the researcher recommends that further research be done which covers other sectors in the country so that possible training programs may be initiated to equip the members of the sectors on a national scale.

\section{Reference}

[1]. Anderson E.W. (1998) Customer Satisfaction and word of mouth / E.W. Anderson // Journal of Service Research. - № 1, Vol. 1. P. 5-17.

[2]. Eugene W, \& Salisbury, Linda Court (2003). The formation of market level.

[3]. Arndt J.(1967) Word-of-mouth advertising: a review of the literature / J. Arndt. - New York : The Advertising Research Foundation Inc,

[4]. Biyalogorsky, E., E. Gerstner, and B. Libai (2001), “Customer Referral Management: Optimal Reward Programs,” Marketing Science, 20 (1), 82-95.

[5]. Bloch, P.H., Sherrell, D.L., Ridgway, N.M. (1986), "Consumer search: an extended

[6]. Blodgett, J.G., Granbois, D.H., Walters, R.G. (1993), "The effects of perceived justice on complainants' negative word-of-mouth behavior and patronage intentions", Journal ofRetailing, Vol. 69 No.4, pp.399-428.

[7]. Brown, J. J., \&Reingen, P. H. (1987). Social ties and word-of-mouth referral behavior. Journal of Consumer Research, 14(3), 350362 .

[8]. Cox, D. F. (1963). The Audiences as Communicators. In S. A. Greyser (Ed.), Proceedings, American Marketing Association, December (pp. 58-72). Chicago: American Marketing Association

[9]. East, R., Hammond, K., Lomax, W., \& Robinson, H. (2005). What is the effect of a recommendation? The Marketing Review, 5(2), $145-157$.

[10]. Eisingerich AB, and Bell SJ (2007). "Maintaining Customer Relationships in High Credence Services,” J. Serv. Mark. 21:253262.expectations and its covariates. Journal of Consumer Research, 30, 115-124.

[11]. Feldman, Sidney P., \& Spencer, Merlin C. (1965). The effect of personal influence in the selection of consumer services. In Peter D. Bennett (Ed.), Fall Conference of the

[12]. Feldman, SP and MC Spencer (1965), "The Effect of Personal Influence in the Selection of Consumer Services," in Marketing and Economic Development, Proceedings of the Fall Conference of the American Marketing Association, Peter D. Bennett, ed. Chicago: American Marketing Association, 440-452. 
[13]. Godes, D. and D. Mayzlin (2004), “Using Online Conversations to Study Word-of-Mouth Communication,” MarketingScience, 23 (4), 545-60.

[14]. Granovetter, M. S. (1973). The strength of weak ties. American Journal of Sociology, 78(6), 1360-1380.Hill information", in Srull, T.K. (Eds),Advances in Consumer Research, Association for Consumer Research, Provo, UT, Vol. 16 pp.23-9. J. And Marsden, P. (Eds.): Connected Marketing: The Viral, Buzz and Word ofJournal of Marketing, Vol. 58, July, pp. 20-38.

[15]. Herr, P.M., Kardes, F.R., Kim, J. (1991), "Effects of word-of-mouth and product-attribute information on persuasion: an accessibility-diagnosticity perspective", Journal of ConsumerResearch, Vol. 17 No.4, pp.454-62.

[16]. 16. Katz, E., \&Lazarsfeld, P. F. (1955). Personal Influence. Glencoe, IL: Free Press.

[17]. Kuokkanen, Juhani (1997), a Link between Consumer Dis/Satisfaction and Post-purchase Word-of-Mouth Intentions: An Experimental Study. Turku: Turku School of Economics and Business Administration.

[18]. Malhotra, N. K. And Birks, D., F. (2006) Marketing Research. An Applied Approach. Prentice Hall, Financial Times. Management Sciences.

[19]. Marx A Van Der Walt (1989) Marketing Management $2^{\text {nd }}$ Edition, Juta\& Co Ltd Cape Town.

[20]. Misner, Ivan R. (1999), The World's Best Known Marketing Secret: Building Your Business with Word-of-Mouth Marketing,2d ed. Austin: Bard Press.

[21]. Moore, R.; Moore, M. (2004), Customer Inquiries and Complaints: the Impact of Firm Response

[22]. Morgan, R.M. and Hunt, S.D. (1994), “The commitment-trust theory of relationship marketing' 'Mouth Revolution, Oxford, Elsevier, pp. 161-185.

[23]. Murray K.B. (1991) A test of services marketing theory: consumer information acquisition activities K.B. Murray Journal of Marketing. Vol. 55. P 10-25.

[24]. Ntale P.D, Muhammad N. And Musiime A. (2013) Relationship marketing, word of mouth communication and consumer loyalty in the Ugandan mobile telecommunication industry,

[25]. Nyilasy, G., 2005, 'Word of mouth - what we really know - and what we don't'. Kirby,

[26]. Richins, M.L., 1983, 'Negative Word-of-Mouth by Dissatisfied Consumers: A Pilot

[27]. Schiffman, L. G., \&Kanuk, L. L. (1995). Consumer Behavior, 9th Ed. Upper Saddle River, NJ: Prentice Hall Study', Journal of Marketing, 47, 1, pp. 68-78.

[28]. Susman, G. Warren, A Ding, M (2006) Product and Service Innovation in Small and Medium-Sized Enterprises, Smeal College of Business The Pennsylvania State University

[29]. Time to Email Communications," Marketing Management Journal, Vol. 14, no 2, p1-12.

[30]. Whyte W.H. (1954) The web of word of mouth / W.H. Whyte // Fortune. № 5, Vol. 50. P. 140-143

[31]. Zaichkowsky, Judith L. (1985), "Measuring the Involvement Construct," Journal of Consumer Research, 12 (3), 341-52

[32]. Zeithaml, Valarie A., \&Bitner, Mari Jo (1996). Services marketing. New York: McGraw- 